\title{
Marinospirillum gen. nov., with descriptions of Marinospirillum megaterium sp. nov., isolated from kusaya gravy, and transfer of Oceanospirillum minutulum to Marinospirillum minutulum comb. nov.
}

\author{
M. Satomi, † B. Kimura, M. Hayashi, Y. Shouzen, M. Okuzumi and T. Fujii
}

Department of Food Science and Technology, Tokyo University of Fisheries, 4-5-7 Konan, Minato-ku, Tokyo 108-8477, Japan
Author for correspondence: T. Fujii. Tel: +8135463 0602. Fax: +81354630602. e-mail: ttfujii@tokyo-u-fish.ac.jp

\begin{abstract}
Two strains of helical, halophilic, Gram-negative, heterotrophic bacteria were isolated from kusaya gravy which is a traditional Japanese fermented brine. These strains were motile by means of a single polar or bipolar tuft flagellum. They had a large cell size, were helical, formed coccoid bodies, were microaerophilic and had quinone type Q-8. The DNA G+C content of the strains was $44-45 \mathrm{~mol} \%$. A detailed investigation of the phenotypic, chemotaxonomic and phylogenetic characteristics of the strains revealed that they represent a new species of halophilic helical bacteria. The sequence of the 16S rRNA gene of strain $\mathrm{H7}^{\top}$, designated the type strain of the new isolates, and all of the Oceanospirillum species except for Oceanospirillum linum were determined. Phylogenetic analysis indicated that these strains were closely related to Oceanospirillum minutulum, with enough distance to separate the 0 . minutulum/new isolate $\mathrm{H}^{\top}$ cluster from Oceanospirillum sensu stricto on the genus level. It is proposed that a new genus, Marinospirillum, be created; this genus should include Marinospirillum minutulum ATCC $19193^{\top}$ (formerly Oceanospirillum minutulum) as the type species, as well as Marinospirillum megaterium JCM $10129^{\top}\left(=\mathrm{H7}^{\top}\right)$.
\end{abstract}

Keywords: Marinospirillum, Oceanospirillum, kusaya gravy, halophilic helical bacteria

\section{INTRODUCTION}

Members of the genus Oceanospirillum are widely distributed in the ocean. Previous studies have isolated several kinds of Oceanospirillum species from putrid marine shellfish (Terasaki, 1972, 1973, 1975, 1979; Watanabe, 1959) and coastal sea water (Baumann et al., 1972: Hylemon et al., 1973; Linn \& Krieg, 1978; Williams \& Rittenberg, 1957). In previous studies (Fujii, 1978; Fujii et al., 1990), Oceanospirillum-like bacteria were isolated from kusaya gravy, which is used for producing Japanese traditional dried fish. The

\footnotetext{
†Present address: National Research Institute of Fisheries Science, Yokohama, Kanagawa, Japan.

Abbreviations: TEM, transmission electron microscopy; $\mathrm{PHB}$, poly- $\beta$ hydroxybutyrate.

The DDBJ accession numbers for the 165 sequences reported in this paper are $A B 006760-A B 006771$
}

main chemical characteristics of kusaya gravy are as follows: low salinity $(\mathrm{NaCl}$ concentration of approximately 3\%) (Fujii, 1977), low dissolved oxygen concentration (Satomi et al., 1997b), and large amounts of volatile basic nitrogen compounds (Fujii, 1977; Satomi et al., 1997b). Microbiologically, the predominant bacteria in kusaya are Corynebacterium-like bacteria (Fujii, 1978; Shimidu et al., 1967, 1969), Peptococcaceae (Fujii et al., 1985, 1993), helical bacteria (Fujii, 1978; Fujii et al., 1990; Kosuge et al., 1978), and bacteria that are unculturable on agar surfaces including the new isolates (Fujii et al., 1990; Satomi et al., 1997b). According to Bergey's Manual of Determinative Bacteriology (Holt et al., 1994), all helical, halophilic, chemo-organotrophic and aerobic bacteria belong to the genus Oceanospirillum. Recently, however, interspecies diversity of this group of bacteria was pointed out by several workers, based on rRNADNA hybridization experiments (Pot et al., 1989), 
fatty acid analysis (Sakane \& Yokota, 1994), isoprenoid quinone analysis (Sakane \& Yokota, 1994) and polyamine composition (Hamana et al., 1994). Thus, the precise identification of halophilic helical bacteria is difficult based on phenotypic characteristics alone. Phenotypically, the new isolates were quite different from other previously described species of this genus in that they had a large cell size and were unable to form colonies on agar plates aerobically. In this study, additional phenotypic and chemotaxonomic characteristics, as well as $16 \mathrm{~S}$ rRNA gene (16S rDNA) sequencing data were obtained. The latter are useful for determining phylogenetic placement and species affiliation. In addition, DNA-DNA hybridization was performed. On the basis of these results, it is proposed that the isolates reported here and Oceanospirillum minutulum should be placed in a new genus, Marinospirillum, and that the new isolates should be placed in a new species, Marinospirillum megaterium.

\section{METHODS}

Bacterial strains and growth conditions. Two strains $\left(\mathrm{H} 7^{\mathrm{T}}\right.$ and SP5) were isolated from kusaya gravy. Both strains were isolated from gravy produced by the same manufacturer but at different times; $\mathrm{H}^{\mathrm{T}}$ was isolated in September 1988 and SP5 was isolated in June 1993. Isolation and purification procedures were as described previously (Fujii et al., 1990). Briefly, a loopful of gravy was used to inoculate the inlet tube of a horizontal glass tube in which the inlet and outlet ends were bent upwards. After an appropriate time, the isolates predominantly accumulated in the outlet because of their excellent motility. By repeating this selective accumulation and purification process alone, the isolates could almost be purified (microscopic observation). Isolation was done by streaking on agar plates. The ability of the new isolates to form colonies on the agar surface was low and was lost after several generations. The isolates ( $\mathrm{H} 7^{\mathrm{T}}$ and SP5) have been deposited in the Japan Collection of Microorganisms (JCM) as Marinospirillum megaterium JCM $10129^{\mathrm{T}}\left(=\mathrm{H} 7^{\mathrm{T}}\right)$ and JCM $10130(=\mathrm{SP} 5)$. These strains were maintained on stab cultures in TSSY semi-solid agar, which contained the following ingredients: $1.7 \%$ trypticase peptone $(\mathrm{BBL}) ; 0 \cdot 3 \%$ phytone peptone $(\mathrm{BBL}) ; 0 \cdot 1 \%$ yeast nitrogen base (Difco); $3.0 \% \mathrm{NaCl}$; and $0.2 \%$ agar. The $\mathrm{pH}$ was adjusted to 8.0 with $1.0 \mathrm{M} \mathrm{NaOH}$. The cultures were incubated for 1 week at $25^{\circ} \mathrm{C}$. To obtain large amounts of cells, cells were incubated in TSSY broth at 90 r.p.m. on a rotary shaker. Cells could not grow in liquid media with vigorous shaking or under static conditions.

Oceanospirillum species were used for comparison; these

Table 1. Designations and/or accession numbers of the genus Marinospirillum and related bacteria analysed in this study

ATCC, American Type Culture Collection, Rockville, MD, USA; IFO, Institute for

Fermentation, Osaka, Japan; and JCM, Japan Collection of Microorganisms, Saitama, Japan.

\begin{tabular}{|c|c|c|}
\hline Species & Strain & $\begin{array}{c}\text { Sequence } \\
\text { accession no. }\end{array}$ \\
\hline Marinospirillum minutulum & ATCC $19193^{\mathrm{T}}\left(=\right.$ IFO $\left.15450^{\mathrm{T}}\right)$ & $\mathrm{AB} 006769^{*}$ \\
\hline Marinospirillum megaterium & $\mathrm{H}^{\mathrm{T}}\left(=\mathrm{JCM} 10129^{\mathrm{T}}\right)$ & $\mathrm{AB} 006770^{*}$ \\
\hline Marinospirillum megaterium & SP5 (=JCM 10130) & \\
\hline Oceanospirillum linum & IFO $15448^{\mathrm{T}}\left(=\mathrm{ATCC} 11336^{\mathrm{T}}\right)$ & M22365 \\
\hline Oceanospirillum maris subsp. maris & ATCC $27509^{\mathrm{T}}$ & $\mathrm{AB} 006771^{*}$ \\
\hline Oceanospirillum maris subsp. hiroshimense & IFO $13616^{\mathrm{T}}$ & $\mathrm{AB} 006762^{*}$ \\
\hline Oceanospirillum maris subsp. williamsae & IFO $15468^{\mathrm{T}}\left(=\mathrm{ATCC} 29547^{\mathrm{T}}\right)$ & $\mathrm{AB} 006763^{*}$ \\
\hline Oceanospirillum beijerinckii subsp. beijerinckii & IFO $15445^{\mathrm{T}}\left(=\mathrm{ATCC} 12754^{\mathrm{T}}\right)$ & $\mathrm{AB} 006760^{*}$ \\
\hline Oceanospirillum beijerinckii subsp. pelagicum & IFO $13612^{\mathrm{T}}\left(=\mathrm{ATCC} 33337^{\mathrm{T}}\right)$ & $\mathrm{AB} 006761^{*}$ \\
\hline Oceanospirillum multiglobuliferum & IFO $13614^{\mathrm{T}}\left(=\mathrm{ATCC} 33336^{\mathrm{T}}\right)$ & $\mathrm{AB} 006764^{*}$ \\
\hline Oceanospirillum japonicum & ATCC $19191^{\mathrm{T}}\left(=\mathrm{IFO} 15446^{\mathrm{T}}\right)$ & $\mathrm{AB} 006766^{*}$ \\
\hline Oceanospirillum kriegii & IFO $15467^{\mathrm{T}}\left(=\mathrm{ATCC} 27133^{\mathrm{T}}\right)$ & $\mathrm{AB} 006767^{*}$ \\
\hline Oceanospirillum jannaschii & IFO $15466^{\mathrm{T}}\left(=\mathrm{ATCC} 27135^{\mathrm{T}}\right)$ & $\mathrm{AB} 006765^{*}$ \\
\hline Oceanospirillum pusillum & IFO $13613^{\mathrm{T}}\left(=\mathrm{ATCC} 33338^{\mathrm{T}}\right)$ & $\mathrm{AB} 006768^{*}$ \\
\hline Deleya salina & ATCC $49509^{\mathrm{T}}$ & X87217 \\
\hline Halomonas elongata & ATCC $33173^{\mathrm{T}}$ & X67023 \\
\hline Marinomonas vaga & ATCC $27119^{\mathrm{T}}$ & X67025 \\
\hline Marinobacter hydrocarbonoclasticus & ATCC $49840^{\mathrm{T}}$ & $\times 67022$ \\
\hline Marinobacterium georgiense & ATCC $700074^{\mathrm{T}}$ & U58339 \\
\hline Volcaniella eurihalina & ATCC $49336^{\mathrm{T}}$ & X87218 \\
\hline Vibrio parahaemolyticus & ATCC $17802^{\mathrm{T}}$ & X56580 \\
\hline Escherichia coli & & $\mathrm{J} 01859$ \\
\hline Proteus vulgaris & IFAM 1731 & $\mathrm{X} 07652$ \\
\hline
\end{tabular}

* Sequenced in this study.

$\dagger$ Consensus sequence of multiple strains. 

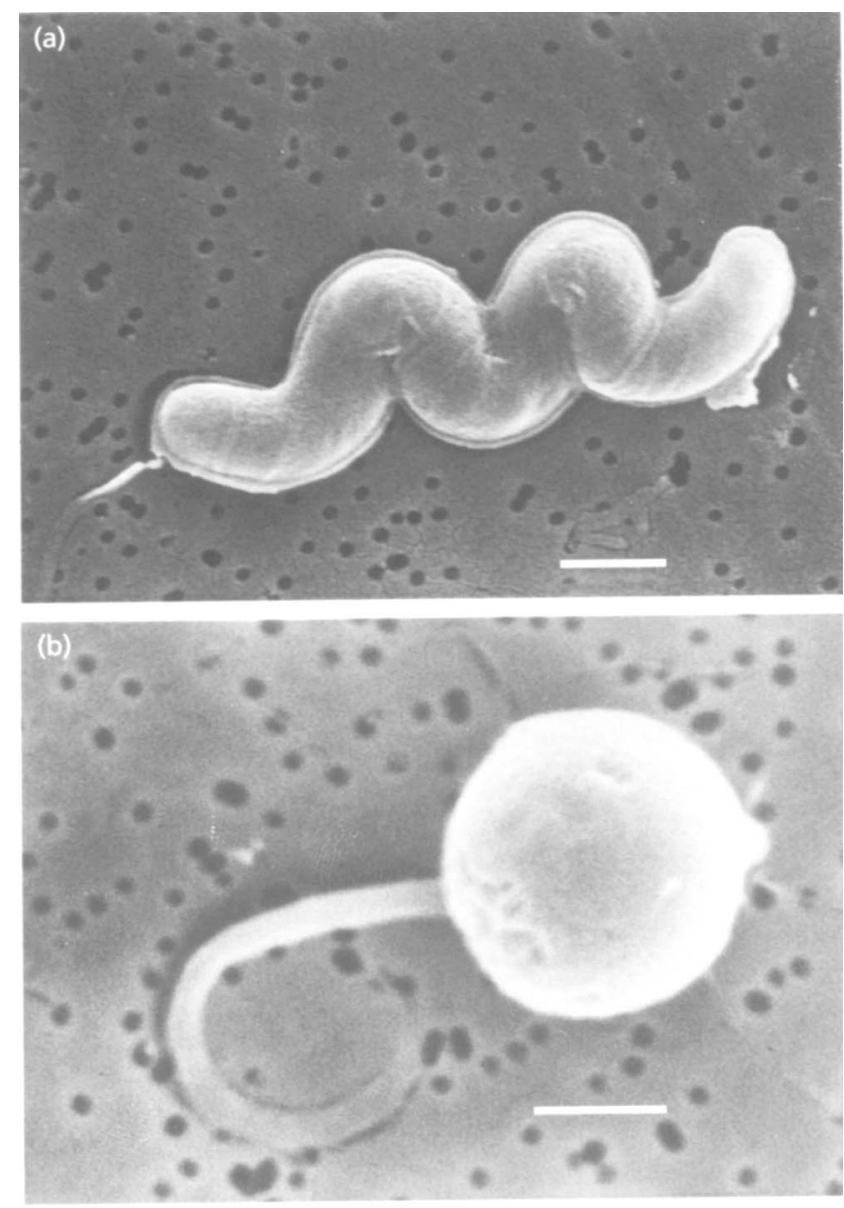

(c)

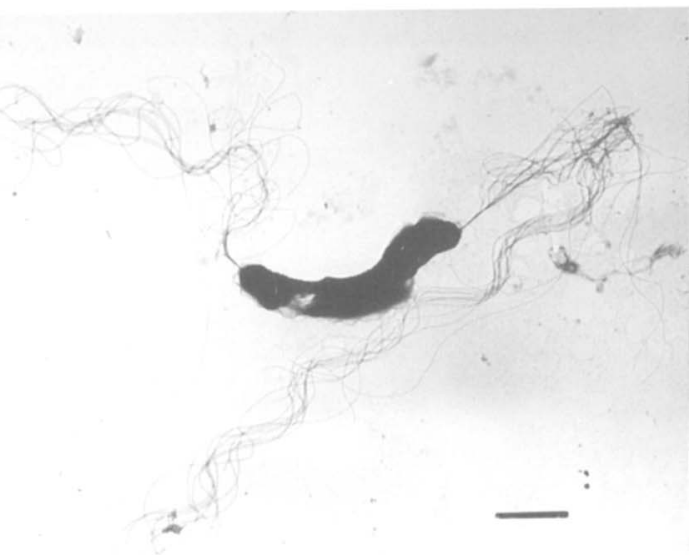

Fig. 1. Scanning electron micrographs of strain $\mathrm{H} 7^{\top}$, vegetative cells (a) and coccoid bodies (b). Negatively stained cells (c) observed by TEM. (a, b) Bar, $1 \mu \mathrm{m}$; (c) bar, $2 \mu \mathrm{m}$.

strains were obtained from the Institute for Fermentation, Osaka (IFO), the American Type Culture Collection (ATCC). and Y. Terasaki (formerly Suzugamine Women's College). The recommended growth media were used to grow these organisms.

Morphology. The cellular morphology of the new isolates, which contained both vegetative and coccoid body cells, and flagella formation were observed by electron microscopy. To obtain the photographs for scanning electron microscopy, cells were fixed for $2 \mathrm{~h}$ in $2 \%$ glutaraldehyde and dehydrated by increasing the concentration of ethanol and isoamyl acetate. Isoamyl acetate was evaporated by critical lyophilization and cells were sputter-coated with gold. Flagella formation was observed by transmission electron microscopy (TEM); cells were stained with uranium acetate. Helix type and motility were observed by phase-contrast microscopy. Gram staining was performed by the modified Hucker procedure (Conn et al., 1957). Accumulation of poly- $\beta$-hydroxybutyrate (PHB) was determined by the Sudan black staining method (Burdon, 1946).

Physiological and biochemical characteristics. Optimum growth temperature, $\mathrm{pH}$ and $\mathrm{NaCl}$ concentration were determined using TSSY semi-solid agar medium. Effects of different oxygen concentrations $(0,3,6,9,12$ and $15 \%)$ on growth of the $\mathrm{H}^{\mathrm{T}}$ isolate were studied on TSSY semi-solid agar medium using a mixed atmosphere consisting of nitrogen and oxygen. Other physiological and biochemical tests were performed in accordance with standard protocols (Krieg, 1984; Pot et al., 1992). Unless indicated otherwise, the inocula used for these tests were prepared from exponential growth stage cells in TSSY semi-solid agar. In the physiological and biochemical tests, Marinospirillum minutulum was used as a reference strain.

Isoprenoid quinone composition. The isoprenoid quinone type and isoprenoid length were analysed using the methods described by Yamada \& Kuraishi (1982). Total acetone soluble extracts of whole cells were separated by onedimensional chromatography on silica gel thin layers (Merck) with benzene for eluent. Isoprenoid length was analysed by HPLC using a reverse-phase column (Cosmosil C18 Econopak column; Nakarai Tesque).

DNA preparation. Cells were suspended in TE buffer ( $\mathrm{pH} 8.0)$ and treated with SDS $(0.5 \%$ final concentration) for lysis. Chromosomal DNA was purified by standard methods (Sambrook et al., 1989) except that the final steps of the procedure were modified as described by Satomi et al. (1997a).

DNA base composition and DNA-DNA homology. The DNA $\mathrm{G}+\mathrm{C}$ content was determined by the HPLC methods of Tamaoka \& Komagata (1984). DNA-DNA homology was studied by microplate hybridization methods (Ezaki et al., 1989) with photobiotin labelling and colorimetric detection as described previously (Satomi et al., 1997a).

165 rDNA sequencing and phylogenetic analysis. 16S rDNA was amplified by PCR. For amplification of $16 \mathrm{~S}$ rDNA, a universal primer set, corresponding to positions 8-27 (forward primer) and 1492-1510 (reverse primer) of the Escherichia coli numbering system, was used (Weisburg et al., 1991). The PCR operating conditions were as described by Suzuki \& Yamasato (1994). The PCR products were visualized by electrophoresis with $1.5 \%$ agarose gel (Nippon Gene) stained with ethidium bromide. Direct sequencing of the amplified DNA fragments was performed as described previously (Satomi et al., 1997a). Similarity of 16S rDNA sequence between strain $\mathrm{H} 7^{\mathrm{T}}$ and other organisms was compared with all sequence data in the GenBank, EMBL and DDBJ databases using the BLAST algorithm (Altschul et al., 1990). Data analysis was performed with CLUSTAL w software (Thompson et al., 1994) as described previously (Satomi et al., 1997a). Nucleotide substitution rates $\left(K_{\text {nur }}\right.$ values) were calculated by the methods of Kimura (1980) 
and a phylogenetic tree was constructed using the neighbourjoining method of Saitou \& Nei (1987). The accession numbers of the new isolates and newly determined reference strains used in the phylogenetic analysis are shown in Table 1.

\section{RESULTS}

\section{Morphology and culture characteristics}

The new strains isolated from kusaya gravy were Gram-negative, rigidly helical (Fig. 1a), and motile. Coccoid body formation was positive after $7 \mathrm{~d}$ culture (Fig. 1b), but no spores were produced. Cell size in optimum conditions was $0.8-1.2 \mu \mathrm{m}$ in diameter by 5-15 $\mu \mathrm{m}$ in length and the thin-wall coccoid body was $2 \cdot 0-2 \cdot 5 \mu \mathrm{m}$ in diameter. Motility was by means of large bipolar tufts of flagella (Fig. 1c).

New isolates required $\mathrm{NaCl}$ for growth; growth was observed at media $\mathrm{NaCl}$ concentrations of $0 \cdot 5-9 \cdot 0 \%$ $(\mathrm{w} / \mathrm{v})$. Optimum growth occurred in $3 \% \mathrm{NaCl}$. These strains grew at temperatures of $4-25^{\circ} \mathrm{C}$, with the optimum temperature for growth at $20-25^{\circ} \mathrm{C}$. The $\mathrm{pH}$ range for growth was $7 \cdot 5-9 \cdot 0$, with the optimum at $\mathrm{pH} 8.0$. In TSSY semi-solid medium, the optimum oxygen concentration was $6 \%$ and growth was not observed at concentrations of $0-3 \%$; cells were thus regarded as microaerophilic. The effects of $\mathrm{H}_{2}$ and $\mathrm{CO}_{2}$ concentrations on growth were not studied. Cells could not grow in liquid media in static or aerobic conditions with vigorous shaking. Moreover, they could not grow on agar plates under all oxygen concentrations studied.

\section{Physiology and biochemical characteristics}

All of the new isolates were oxidase-positive and did not catabolize carbohydrates. Intracellular PHB was formed. Nitrate reduction and denitrifying activity were negative. The catalase reaction was negative or weakly positive. The DNA G $+\mathrm{C}$ contents of the two new isolates, $\mathrm{H}^{\mathrm{T}}$ and SP5, were 44.4 and $44.8 \mathrm{~mol} \%$, respectively. Biochemical and physiological characteristics useful for identifying and differentiating the new isolates and $O$. minutulum are shown in Table 2. The characteristics of both species given in Table 2 were studied under the same conditions.

\section{Isoprenoid quinone analysis}

The isoprenoid quinone composition of strain $\mathrm{H} 7^{\mathrm{T}}$ was determined. It contained ubiquinone, which consisted of mainly Q-8. In this new isolate, a small amount of menaquinone was detected, but too little for precise analysis.

\section{S rRNA gene sequence comparisons}

To investigate the phylogenetic relationships of the new isolates, the 16S rDNA sequences of the representative strain $\mathrm{H}^{\mathrm{T}}$ and of all of the Oceanospirillum species, except for Oceanospirillum linum, already deposited in the database were determined. The sequences obtained in this study were aligned together with reference sequences from the DDBJ database. Sequence comparisons and phylogenetic analysis are

Table 2. Characteristics which differentiate the new helical bacteria isolated from kusaya gravy and $M$. minutulum

Both species were Gram-negative spirals that formed coccoid bodies but did not form spores. They were motile by means of a polar tuft flagellum, accumulated PHB and had a positive oxidase reaction; the cell shape helix type was anticlockwise and the major isoprenoid quinone type was Q-8. All strains were negative for acid production from sugars, production of pigment, indole, and $\mathrm{H}_{2} \mathrm{~S}$, and hydrolysis of casein, aesculin, gelatin, hippurate and starch. None of the strains produced DNase, RNase, phosphatase or urease.

\begin{tabular}{|c|c|c|}
\hline Characteristic & New isolates $\left(\mathrm{H} 7^{\mathrm{T}}\right.$ and SP5) & M. minutulum ATCC $19193^{\top}$ \\
\hline Cell length $(\mu \mathrm{m})$ & $5-15$ & $2-2 \cdot 8$ \\
\hline Cell diameter $(\mu \mathrm{m})$ & $0 \cdot 8-1 \cdot 2$ & $0 \cdot 3-0 \cdot 4$ \\
\hline Oxygen requirement* & $\mathrm{Mi}$ & $\mathrm{Ae}$ \\
\hline Catalase & - or $\mathrm{W}_{\dagger}^{\dagger}$ & + \\
\hline Reduction of nitrate & - & + \\
\hline Temperature range for growth $\left({ }^{\circ} \mathrm{C}\right)$ & $4-25$ & 430 \\
\hline Range of $\mathrm{NaCl}(\%)$ for growth & $0 \cdot 5-9 \cdot 0$ & $0 \cdot 2-10 \cdot 0$ \\
\hline Range of $\mathrm{pH}$ for growth & $7 \cdot 5-9 \cdot 0$ & $7 \cdot 0-10 \cdot 5$ \\
\hline \multicolumn{3}{|l|}{ Growth in the presence of: } \\
\hline $1 \%$ Glycine & - & + \\
\hline I $\%$ Ox gall & - & + \\
\hline $\mathrm{DNA} \mathrm{G}+\mathrm{C}(\mathrm{mol} \%)$ & $44-45$ & $42 \cdot 5+$ \\
\hline
\end{tabular}

* Mi, Microaerophilic; Ae, aerophilic.

$\dagger \mathrm{W}$, Weak reaction, i.e. several bubbles were observed in the catalase test performed on centrifuged cells or on cell debris sonically disrupted in neutralization buffer.

† Data from Sakane \& Yokota (1994). 
Marinospirillum gen. nov., new halophilic helical bacteria

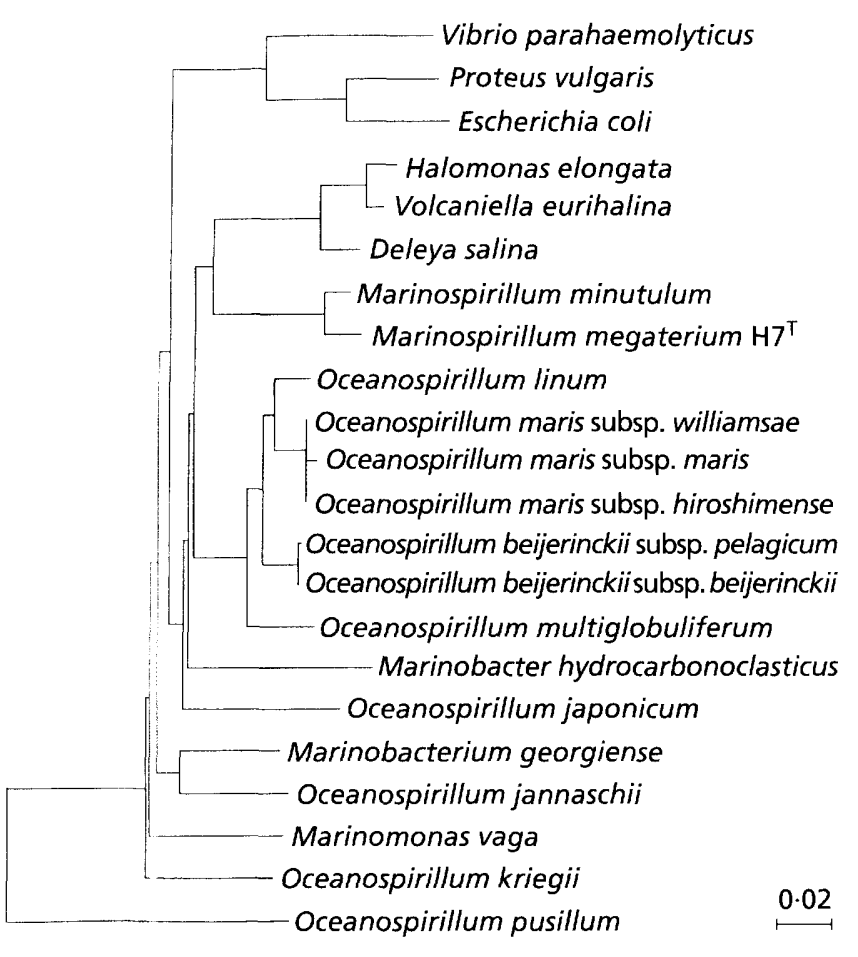

Fig. 2. Phylogenetic tree constructed by the neighbour-joining method based on 16S rDNA sequences of new isolate $\mathrm{H}^{\top}$ and related bacteria. Bar, $0.02 K_{\text {nuc }}$.

shown in Fig. 2. The $16 \mathrm{~S}$ rDNA sequence of $\mathrm{H} 7^{\mathrm{T}}$ was most similar (level of sequence similarity was $97.5 \%$ ) to the sequence of $O$. minutulum; other reference strains exhibited only low levels of similarity (less than $90 \%$ ). On the phylogenetic tree of $16 \mathrm{~S}$ rDNA, Oceanospirillum kriegii, Oceanospirillum jannaschii, Oceanospirillum japonicum and $O$. minutulum had separate positions among the $\gamma$-subclass Proteobacteria (Stackebrandt et al., 1988); Oceanospirillum pusillum belongs to the $\alpha$-subclass Proteobacteria (Woese et al., 1985).

\section{DNA-DNA hybridization}

Table 3 shows the levels of DNA-DNA relatedness among the strains studied. DNA-DNA hybridization experiments performed with labelled DNAs from strains $\mathrm{H} 7^{\mathrm{T}}, O$. minutulum and $O$. linum revealed that the new isolates were closely related to each other but exhibited relatively low levels of hybridization (about $30 \%$ ) with $O$. minutulum. No meaningful DNA-DNA hybridization was recognized between the new isolates/O. minutulum group and $O$. linum.

\section{DISCUSSION}

The results of these phenotypic, chemotaxonomic and phylogenetic analyses clearly indicate that the new strains $\left(\mathrm{H} 7^{\mathrm{T}}\right.$ and SP5), isolated from kusaya gravy in Japan, form a homogeneous group and represent a new species of halophilic helical bacteria. These bacteria are Gram-negative, rigidly helical, non-sporeproducing, coccoid body-forming, motile, halophilic, microaerobic and PHB-accumulating. They are also oxidase-positive, do not catabolize carbohydrates or reduce nitrate, and are unable to grow with $1 \%$ ox gall and glycine. The catalase reaction is negative or weakly positive. Usually, they cannot grow on agar surfaces. They have genomic DNA G+C contents of 44 $45 \mathrm{~mol} \%$. The isoprenoid quinone type of strain $\mathrm{H}^{\mathrm{T}}$ is Q-8. Their genotypic and chemotaxonomic characteristics indicate that the new isolates are similar to members of the genus Oceanospirillum. However, their taxonomic place could not be determined exactly, since phenotypically they were quite different from other species in this genus in their large cell size and inability to grow on agar surfaces. Based on rRNADNA hybridization experiments, Pot et al. (1989) reported that the taxonomic relationships in this genus

Table 3. Levels of DNA-DNA reassociation between new isolates and Oceanospirillum species

\begin{tabular}{|c|c|c|c|}
\hline \multirow[t]{2}{*}{ Source of unlabelled DNA } & \multicolumn{3}{|c|}{ Relatedness (\%) to labelled DNA from: } \\
\hline & $\mathbf{H} 7^{\mathrm{T}}$ & ATCC $19193^{T}$ & IFO $15448^{\mathrm{T}}$ \\
\hline M. megaterium $\mathrm{H}^{7}\left(=\mathrm{JCM} 10129^{\mathrm{T}}\right)$ & 100 & 32 & 7 \\
\hline M. megaterium SP5 (=JCM 10130) & 100 & 28 & 7 \\
\hline M. minutulum ATCC $19193^{\mathrm{T}}$ & 28 & 100 & 5 \\
\hline O. linum IFO $15448^{\mathrm{T}}$ & 5 & 8 & 100 \\
\hline O. maris subsp. hiroshimense IFO $13616^{\mathrm{T}}$ & 12 & 7 & 37 \\
\hline O. beijerinckii subsp. beijerinckii IFO $15445^{T}$ & 4 & 6 & 21 \\
\hline O. multiglobuliferum IFO $13614^{\mathrm{T}}$ & 8 & 8 & 17 \\
\hline O. japonicum ATCC $19191^{\mathrm{T}}$ & 12 & 8 & 7 \\
\hline O. jannaxchii IFO $15466^{\mathrm{T}}$ & 2 & 6 & 9 \\
\hline O. kriegii IFO $15467^{\mathrm{T}}$ & 7 & 8 & 10 \\
\hline O. pusillum IFO $13613^{\mathrm{T}}$ & 2 & 2 & 2 \\
\hline
\end{tabular}


were heterogeneous. This suggestion was confirmed by the studies of fatty acid, quinone and polyamine composition (Hamana et al., 1994; Sakane \& Yokota, 1994). 16S rDNA sequence analysis, which is a reliable method for determining species affiliations, was carried out in this study. A comparative sequence analysis of $16 \mathrm{~S}$ rDNA revealed that strain $\mathrm{H}^{\mathrm{T}}$ and $O$. minutulum are closely related (similarity of $97.5 \%$ ), but they could be distinguished as different species by their phenotypic features and phylogenetic distance. The low levels of $16 \mathrm{~S}$ rDNA sequence similarity between strain $\mathrm{H} 7^{\mathrm{T}} / O$. minutulum group and other halophilic helical bacteria indicated that these bacteria are phylogenetically different enough to be different genera. This notion is strongly supported by the DNA-DNA hybridization results, which satisfy the recommendation of the Ad Hoc Committee on reconciliation of approaches to bacterial systematics (Wayne et al., 1987). The phylogenetic tree of $16 \mathrm{~S}$ rDNA (Fig. 2) indicates that the genus Oceanospirillum is clearly a heterogeneous group and their phylogenetic relationships are supported by the results of rRNA-DNA hybridization reported by Pot et al. (1989) except in the case of $O$. japonicum. These previous results and those presented here suggest that the genus Oceanospirillum consists of $O$. linum, which is the type species of this genus, Oceanospirillum maris, Oceanospirillum beijerinckii and Oceanospirillum multiglobuliferum. Other species, $O$. jannaschii, $O$. japonicum, $O$. kriegii, $O$. minutulum and $O$. pusillum, should be eliminated from this genus and transferred to another genus. Determination of their precise taxonomic positions needs further study to detect other, possibly more closely related organisms to these species. In this report, $O$. japonicum is not included in Oceanospirillum species, because it could not form a coccoid body (Hylemon et al., 1973; Krieg, 1984; Watanabe, 1959) and did not cluster with Oceanospirillum sensu stricto at levels suitable for the same genus based on 16S rDNA sequences. The exclusion of $O$. japonicum from the genus is supported by the insignificant degree of reassociation between its DNA and DNA from $O$. linum.

On the basis of phenotypic, chemotaxonomic and phylogenetic studies, it is concluded that the new isolates should be classified as new species belonging to the same genus as $O$. minutulum. Therefore, it is proposed that a new genus, Marinospirillum, should be created for the new isolates and $O$. minutulum.

Several phenotypic features allowed differentiation between $O$. minutulum and the new isolates (Table 2), and the low levels of DNA similarity on both organisms (similarity levels based on DNA-DNA hybridization of about $30 \%$ ) justify placing them in different species. Thus, the name Marinospirillum megaterium sp. nov. is proposed; strain $\mathrm{H} 7^{\mathrm{T}}$ is the type strain of this species. Oceanospirillum minutulum should be transferred to the genus Marinospirillum as Marinospirillum minutulum.

\section{Description of Marinospirillum gen. nov.}

Marinospirillum (Ma.ri.no.spi.ril'lum. L. adj. marinus of the sea; Gr. n. spira a spiral; M.L. dim. neut. n. spirillum a small spiral; Marinospirillum a small spiral from the sea).

Gram-negative, rigidly helical, non-spore-producing, coccoid body-forming, halophilic, aerobic or microaerobic, chemo-heterotrophic and PHB-accumulating bacteria. Motile by means of flagella. Oxidase-positive. Catalase reaction is negative or positive. Carbohydrates are not catabolized. Genomic DNA $\mathrm{G}+\mathrm{C}$ content of $42-45 \mathrm{~mol} \%$ (as determined by HPLC). The isoprenoid quinone type is Q-8. The type species is Marinospirillum minutulum.

\section{Description of Marinospirillum megaterium sp. nov.}

Marinospirillum megaterium (me.ga.te'ri.um. Gr. adj. mega large; Gr. n. teras, teratis monster, beast; M.L. n. megaterium big beast).

In addition to those given above in the description of the genus, $M$. megaterium has the following characteristics. Rigid helical shaped cells are $0 \cdot 8-1 \cdot 2 \mu \mathrm{m}$ in diameter by $5-15 \mu \mathrm{m}$ in length and thin-wall coccoid bodies are $2.0-2.5 \mu \mathrm{m}$ in diameter. $\mathrm{NaCl}$ is required for growth; growth occurs at $\mathrm{NaCl}$ concentrations of $0 \cdot 5-9.0 \%(\mathrm{w} / \mathrm{v})$ and is optimal at $3 \% \mathrm{NaCl}$. The temperature range for growth is $4-25^{\circ} \mathrm{C}$, with an optimum of $20-25^{\circ} \mathrm{C}$. The $\mathrm{pH}$ range for growth is $7 \cdot 5-9 \cdot 0$, with an optimum of $\mathrm{pH} 8 \cdot 0$. Cells were microaerophilic. Cells cannot grow in liquid media in static or aerobic conditions with vigorous shaking or on plate surfaces. Catalase production is weakly positive. Gelatin, hippurate and starch are not hydrolysed. Nitrate is not reduced. DNase, RNase, urease and phosphatase are not produced. The DNA G + C content is $44-45 \mathrm{~mol} \%$. The type strain is strain $\mathrm{H}^{\mathrm{T}}$ $\left(=\mathrm{JCM} 10129^{\mathrm{T}}\right)$, which was isolated from kusaya gravy.

\section{Transfer of Oceanospirillum minutulum to the genus Marinospirillum as Marinospirillum minutulum comb. nov.}

Marinospirillum minutulum (mi.nu'tu.lum. L. dim. neut. adj. minutulum very little).

Physiological, chemotaxonomic and phylogenetic data indicate that $O$. minutulum is more closely related to $M$. megaterium than to $O$. linum, the type species of the genus Oceanospirillum. The original description of the species given by Watanabe (1959) is unchanged.

\section{ACKNOWLEDGEMENTS}

The authors thank Dr Y. Terasaki for providing us with bacterial strains and for his useful advice in phenotypic identification, Dr Y. Ishida and Dr A. Uchida (Kyoto University, Kyoto, Japan) for their advice in the 16S rDNA sequences analyses, Mr T. Maeda (Marukaku-Suisan Co., Niijima Island, Japan) for providing us with the kusaya gravy samples. This study was partly supported by a Grant- 
in-Aid from the Ministry of Education, Science and Sports and Culture of Japan (B 09460094).

\section{REFERENCES}

Altschul, S. A., Gish, W., Miller, W., Myers, E. W. \& Lipman, D. J. (1990). Basic local alignment search tool. $J \mathrm{Mol}$ Biol 215 , 403-410.

Baumann, L., Baumann, P., Mandel, M. \& Allen, R. D. (1972). Taxonomy of aerobic marine eubacteria. J Bacteriol $\mathbf{1 1 0}$, 402-429.

Burdon, K. L. (1946). Fatty material in bacteria and fungi revealed by staining dried, fixed slide preparations. $J$ Bacteriol 52, 665-678.

Conn, H. J., Bartholomew, J. W. \& Jennison, M. W. (1957). Staining methods. In Manual of Microbiological Methods, pp. 10-36. Edited by Society of American Bacteriologists. New York: McGraw-Hill.

Ezaki, T., Hashimoto, Y. \& Yabuuchi, E. (1989). Fluorometric deoxyribonucleic acid-deoxyribonucleic acid hybridization in microdilution wells as an alternative to membrane filter hybridization in which radioisotopes are used to determine genetic relatedness among bacterial strains. Int J Syst Bacteriol 39, 224-229.

Fujii, T. (1977). Studies on 'Kusaya'-I. Comparison of composition of 'Kusaya' brine at Niijima and Oshima islands. Nippon Suisan Gakkaishi 43, 517-521.

Fujii, T. (1978). Microbial fiora of 'Kusaya' brine of Niijima and Oshima islands. Nippon Suisan Gakkaishi 44, 45-48.

Fujii, T., Sugita, H. \& Deguchi, Y. (1985). Obligately anaerobic bacteria isolated from 'Kusaya' gravy. Nippon Suisan Gakkaishi 51, 473-478.

Fujii, T., Hayashi, M. \& Okuzumi, M. (1990). New device for isolation of spiral bacteria from 'Kusaya' gravy. Nippon Suisan Gakkaishi 56, 1661.

Fujii, T., Kuda, T. \& Okuzumi, M. (1993). Anaerobic microflora of 'Kusaya' gravy. Nippon Suisan Gakkaishi 59, 185.

Hamana, K., Sakane, T. \& Yokota, A. (1994). Polyamine analysis of the genera Aquaspirillum, Magnetospirillum, Oceanospirillum, and Spirillum. J Gen Appl Microbiol 40, 75-82.

Holt, J. G., Krieg, N. R., Sneath, P. H. A., Staley, J. T. \& Williams, S. T. (1994). Bergey's Manual of Determinative Bacteriology, 9th edn. Baltimore: Williams \& Wilkins.

Hylemon, P. B., Wells, J. S., Jr, Krieg, N. R. \& Jannasch, H. W. (1973). The genus Spirillum: a taxonomic study. Int $J$ Syst Bacteriol 23, 340-380.

Kimura, M. (1980). A simple method for estimating evolutionary rates of base substitutions through comparative studies of nucleotide sequences. $J$ Mol Biol 16, 111-120.

Kosuge, T., Yokota, M., Ohba, H. \& Nagano, H. (1978). Study on kusaya-I. Antiseptic effects of kusaya brine. Nippon Suisan Gakkaishi 44, 1141-1146.

Krieg, N. R. (1984). Aerobic/microaerophilic, motile, helical/ vibrioid Gram-negative bacteria. In Bergey's Manual of Systematic Bacteriology, vol. 1, pp. 71-95. Edited by N. R. Krieg \& J. G. Holt. Baltimore: Williams \& Wilkins.

Linn, D. M. \& Krieg, N. R. (1978). Occurrence of two organisms in cultures of the type strain of Spirillum lunatum: proposal for rejection of the name Spirillum lunatum and characterization of Oceanospirillum maris subsp. williamsae and an unclassified vibrioid bacterium. Int J Syst Bacteriol 28, 132-138.

Pot, B., Gillis, M., Hoste, B., Van De Velde, A., Bekaert, F.,
Kersters, K. \& De Ley, J. (1989). Intra- and intergenetic relationships of the genus Oceanospirillum. Int J Syst Bacteriol 39, 23-34.

Pot, B., Gillis, M. \& De Ley, J. (1992). The genus Oceanospirillum. In The Prokaryotes. A Handbook on the Biology of Bacteria: Ecophysiology, Isolation, Identification, Applications, 2nd edn, vol. 4, pp. 3230-3236. Edited by A. Balows, H. G. Trüper, M. Dworkin, W. Harder \& K.-H. Schleifer. New York: SpringerVerlag.

Saitou, N. \& Nei, M. (1987). The neighbor-joining method: a new method for reconstructing phylogenetic trees. Mol Biol Evol 4 406-425.

Sakane, T. \& Yokota, A. (1994). Chemotaxonomic investigation of heterotrophic, aerobic and microaerophilic spirilla, the genera Aquaspirillum, Magnetospirillum, and Oceanospirillum. Syst Appl Microbiol 17, 128-134.

Sambrook, J., Fritsch, E. F. \& Maniatis, T. (1989). Molecular Cloning: a Laboratory Manual, 2nd edn. Cold Spring Harbor, NY: Cold Spring Harbor Laboratory.

Satomi, M., Kimura, B., Mizoi, M., Satou, T. \& Fujii, T. (1997a). Tetragenococcus muriaticus sp. nov., a new moderately halophilic lactic acid bacterium isolated from fermented squid liver sauce. Int J Syst Bacteriol 47, 832-836.

Satomi, M., Kimura, B., Takahashi, G. \& Fujii, T. (1997b). Microbial diversity of kusaya gravy. Fish Sci (Tokyo) 63, 1019-1023.

Shimidu, A., Mochizuki, A., Shimizu, U. \& Aiso, K. (1967). Studies of kusaya-I. Chemical composition and preserving effect of the curing brine for kusaya. Nippon Suisan Gakkaishi 33, 11431146.

Shimidu, U., Aiso, K., Shimidu, W. \& Mochizuki, A. (1969). Studies of kusaya-II. Microbiological examination of a kusaya brine. Nippon Suisan Gakkaishi 35, 109-115.

Stackebrandt, E., Murray, R. G. E. \& Trüper, H. G. (1988). Proteobacteria classis nov., a name for the phylogenetic taxon that includes the "Purple bacteria and their relatives". Int J Syst Bacteriol 38, 321-325.

Suzuki, T. \& Yamasato, K. (1994). Phylogeny of spore-forming lactic acid bacteria based on $16 \mathrm{~S}$ rRNA gene sequences. FEMS Microbiol Lett 115, 13-18.

Tamaoka, J. \& Komagata, K. (1984). Determination of DNA base composition by reversed-phase high performance liquid chromatography. FEMS Microbiol Lett 25, 125-128.

Terasaki, Y. (1972). Studies on the genus Spirillum Ehrenberg. I. Morphological, physiological, and biochemical characteristics of water spirilla. Bull Suzugamine Women's Coll Nat Sci 16, $1-46$.

Terasaki, Y. (1973). Studies on the genus Spirillum Ehrenberg. II. Comments on type and reference strains of Spirillum and description of new species and new subspecies. Bull Suzugamine Women's Coll Nat Sci 17, 1-71.

Terasaki, Y. (1975). Freeze-dried cultures of water spirilla made on experimental basis. Bull Suzugamine Women's Coll Nat Sci 19, $1-10$.

Terasaki, Y. (1979). Transfer of five species and two subspecies of Spirillum to other genera (Aquaspirillum and Oceanospirillum), with emended descriptions of the species and subspecies. Int $J$ Syst Bacteriol 29, 130-144.

Thompson, J. D., Higgins, D. G. \& Gibson, T. J. (1994). CLUSTAL $\mathrm{W}$ : improving the sensitivity of progressive multiple sequence alignment through sequence weighting, position-specific gap penalties and weight matrix choice. Nucleic Acids Res 22, $4673-4680$. 
Watanabe, N. (1959). On four new halophilic species of Spirillum. Bot Mag Tokyo 72, 77-86.

Wayne, L. G., Brenner, D. J., Colwell, R. R. \& 9 other authors (1987). International Committee on Systematic Bacteriology. Report of the ad hoc committee on reconciliation of approaches to bacterial systematics. Int J Syst Bacteriol 37, 463-464.

Weisburg, W. G., Barns, S. M., Pelletier, D. A. \& Lane, D. J. (1991). 16 S ribosomal DNA amplification for phylogenetic study. $J$ Bacteriol 173, 697-703.

Williams, M. A. \& Rittenberg, S. C. (1957). A taxonomic study of the genus Spirillum Ehrenberg. Int Bull Bacteriol Nomencl Taxon 7, 49-111.

Woese, C. R., Weisburg, W. G., Hahn, C. M., Paster, B. J., Zablen, L. B., Lewis, B. J., Macke, T. J., Ludwig, W. \& Stackebrandt, E. (1985). The phylogeny of purple bacteria: the gamma subdivision. Syst Appl Microbiol 6, 25-33.

Yamada, Y. \& Kuraishi, I. (1982). Ubiquinone and Menaquinone. In Biseibutsu no Kagakubunrui Jikkenhou, pp. 143-155. Edited by K. Komagata. Tokyo: Gakkai Shuppan Center (in Japanese). 